https://helda.helsinki.fi

\title{
Nordic Legal Mind
}

\section{Letto-Vanamo, Pia Tellervo}

Springer

2019

Letto-Vanamo , P T \& Tamm , D 2019 , Nordic Legal Mind . in P Letto-Vanamo , D Tamm \& B O G Mortensen (eds), Nordic Law in European Context . Ius Gentium: Comparative Perspectives on Law and Justice, vol. 73 , Springer, Cham , pp. 1-19 . https://doi.org/10.1007/978-3-030-03006-3

http://hdl.handle.net/10138/308107

https://doi.org/10.1007/978-3-030-03006-3_1

unspecified

acceptedVersion

Downloaded from Helda, University of Helsinki institutional repository.

This is an electronic reprint of the original article.

This reprint may differ from the original in pagination and typographic detail.

Please cite the original version. 


\section{Nordic Legal Mind}

Pia Letto-Vanamo and Ditlev Tamm

Letto-Vanamo, University of Helsinki, Faculty of Law, Helsinki, Finland

Tamm, University of Copenhagen, Faculty of Law, Denmark, Copenhagen

\section{Abstract}

\section{Nordic Law}

There is no such thing as Nordic law, but you may talk of a Nordic legal mind. The Nordic countries, Denmark, Finland, Iceland, Norway, and Sweden (including the autonomous regions of Greenland, and the Faroe and Åland islands) all have their own law and their own legal institutions. However, to speak of Nordic law may be useful as we need a concept that covers those peculiarities and similarities which, with certain reservations, can be considered as such characteristic and common features in dealing with the legal systems of these countries, which constitute the Nordic legal mind.

Comparative lawyers trying to grasp European legal systems have traditionally put the Nordic countries together as one legal "family" or group, or at least as a subfamily of the continental European so-called "civil law family". ${ }^{1}$ This classification can at least partly be explained by reference to history. Still, the idea of "Nordic-ness" is more recent. In a comparative analysis, the peculiarities of development seen in the Nordic legal system(s) are often explained by reference to a certain historical delay in accepting such ideas and institutions which are considered as belonging to the "European mainstream". We may also speak of the centre and the periphery, to which the Nordic countries belong due to their geographical position.

However, only in the $19^{\text {th }}$ century did the idea of a specific "Nordic law" become a current notion to substitute the old division between DanishNorwegian law on the one hand and Swedish law (including Finland) on the other, and then especially as a tool to promote cooperation in the field of law. Since then, Nordic unity, or the Nordic legal family, was formed by

${ }^{1}$ Zweigert K, Kötz H (1998), Husa J (2004); Husa J (2015). 
active cooperation through which former differences were bridged: "Nordic law" resulted from those efforts. It started in 1872, when several prominent Nordic lawyers were invited to the first meeting between lawyers from all the Nordic countries with the aim of discussing common answers to the challenges, which the Nordic countries and their laws were facing at a time of still early industrialisation. The inspiration for the meeting came from similar German and English institutions. ${ }^{2}$

One of the main arguments put forward in favour of Nordic cooperation by those invited to this first meeting of Nordic lawyers ${ }^{3}$ referred to what was considered a common way of legal thinking. That was based on an ideology that stressed more similarities than differences by looking back on the historical origins of law in the Nordic countries. Un understanding of the characteristics of Nordic legal thinking therefore requires taking into account both the idea of historical similarities between the legal systems of the Nordic countries along with advanced legal cooperation.

Nordic legislative cooperation has featured significantly in framing legal systems in the Nordic countries as they are today. Nordic cooperation as it developed and gradually covered many fields of law has also been seen as an ideal model for legal cooperation elsewhere because of its informal and voluntary nature and its success, ${ }^{4}$ especially at a time when European legal cooperation was still in its very early stages. ${ }^{5}$

This fruitful cooperation started in the 1870s, and has perhaps been the most enduring result of the so-called Scandinavian movement of the early $19^{\text {th }}$ century, which after the experience of centuries of warfare between the Nordic countries pleaded for unity, collaboration and friendship among the nations of the North. Scandinavism, as this movement is called, however,

\footnotetext{
2 Tamm D (1972), Carsten G (1973).

${ }^{3}$ Since the first meeting of Nordic lawyers in Copenhagen in 1872, these have been held every three years except for the periods between 1903-1918 and 1938-1947. The latest meeting (Helsinki, 2017) was attended by around 900 lawyers - judges, civil servants, practising lawyers and legal scholars - from all the Nordic countries. To enhance their importance for general debate on law, since the first meetings conference papers, talks and partly also discussions among participants have been printed and published. See http://www.nordisktjuristmote.org/. Accessed 18 July 2018.

${ }^{4}$ Smits J (2007), Matteucci M (1956).

${ }^{5}$ Matteucci M (1956).
} 
failed completely as a political movement that might lead to unification of the Nordic countries, an idea that proved Utopian.

All the Nordic countries were and are rather small, and many at that time topical questions were unknown to their scholars. Lawyers experienced in commercial matters did not abound, especially not such as could really be considered experts in new and complicated legal fields. Working together and using the potential from several states was the obvious solution, and became an immediate success. Not only Nordic lawyers' meetings but also harmonization of Nordic law experienced their beginnings in the 1870s. Since then, active legislative collaboration has been a decisive feature in classifying the Nordic countries as a legal family closer to civil-law countries (countries with statutory law) than to so-called common law countries (countries with case law), or even as a family of its own.

The purpose of Nordic legal cooperation was to find a Nordic way of jointly approaching questions posed by the rapid development of international commerce. Challenges were posed by new instruments of payment in commercial life, changes in methods of communication, and, in general, issues attached to industry on a greater scale and to questions of international trade. ${ }^{6}$

Since that time, the way the cooperation works is that common new legal solutions are discussed among representatives of the different countries, but at the same time it is left to the lawmakers of each country and thus to a political decision whether and to what degree any such new legislation will actually be drafted and adopted in their country. Nor does cooperation mean that common courts or other organs have been established to create what could be called a "Nordic common law"7 based on Nordic legislation. At the same time, national lawyers, judges or law professors are free to make their own interpretations of the law.

\footnotetext{
${ }^{6}$ When the first Nordic lawyers' meeting was convened, the invitation stressed that because of a common understanding of law and of the common origin of many legal institutions, it was only natural that development of those institutions would need common action. The topics mentioned for cooperation were the law of commerce and issues of court procedure in civil and penal matters. During the first meeting in 1872, the question was raised of common Nordic legislation on commercial instruments of payment such as the bill of exchange, which was a means of getting short credit. This was successfully followed up by Nordic statutes; Carsten G (1993).

${ }^{7}$ Common law here in the meaning of H. Patrick Glenn; Glenn HP (2005).
} 
Thus, in contrast to the European Union (EU) regime, there is neither such a thing as a common Nordic judiciary nor any other kind of common legal organs, nor any common legal thinking. Court decisions, legal rules or legal literature are national, while those of other Nordic countries may be and will regularly be cited, but basically they only serve an advisory function in the same way as any other foreign law or can be used as sources of inspiration when making decisions. Also quite rarely, law students will be familiar with legal literature from other Nordic countries than their own.

Nonetheless, this "soft" method of harmonizing the law, which does not aim at unification but which respects local peculiarities and wishes, has led to an impressive series of important statutes within basic fields of law, such as commercial law especially with common statutes on the law of buying and selling and the law of contracts $^{8}$, but also within fields often considered more national and culturally sensitive such as family law ${ }^{9}$. Based on some of these statutes, general principles of law have also been developed which in other continental legal systems are found in the general part of the civil code.

In the 1970s, Nordic legal cooperation suffered a crisis, as will be mentioned later, when the Swedish minister of justice declared at the 1972 Nordic lawyers' meeting that Sweden might decide to go its own way, especially in economic and family law matters, and not wait for the other Nordic countries. ${ }^{10}$ Moreover, within the field of law of obligations problems have arisen in finding a common path to follow. Thus, the Nordic law of sale of goods that was discussed and drafted in the 1980s was not accepted in all the Nordic countries. Sweden and Finland preferred identical laws, and Norway had a very similar one. However, in Denmark the Nordic Sale of Goods Act was not accepted and the Danes preferred to amend the old Sale of Goods Act of 1906. ${ }^{11}$

\footnotetext{
${ }^{8}$ See further Bärlund $\mathrm{J}$ and Moegelvang-Hansen $\mathrm{P}$ in this book.

${ }^{9}$ See further Lund-Andersen I and Kronborg A in this book.

${ }^{10}$ Lidbom C (1973), Modéer KÅ (1978).

${ }^{11}$ Se further Bärlund $\mathrm{J}$ and Moegelvang-Hansen $\mathrm{P}$ in this book.; On differences in regulation of registred partnership see further Lund-Andersen I and Kronborg A in this book.
} 
For some decades now, great challenges to Nordic law and legal cooperation have been posed by the much wider cooperation taking part within the EU. Indeed, from time to time the issue whether Nordic cooperation has seen its heyday comes under discussion. In particular, the 1990s witnessed a boom of seminars and meetings on "Nordic legal identity" and its future. The main reason for this was the upcoming or recently achieved Finnish and Swedish membership in the European Union. The laws of the Nordic countries were compared with other European (EU) countries with the aim of determining what could be considered similarities between the Nordic legal systems on the one hand, and differences between them and other Western European countries on the other. In effect, this was an effort to foresee whether a kind of so-called "convergence" on a greater scale would happen through EU membership, and also what would be the impact on Nordic cooperation. ${ }^{12}$

Undeniably, Nordic cooperation within the field of law has been challenged by cooperation within the EU, based on institutions and the creation of obligations much more effective than the soft guidelines and voluntary arrangements that form the basis of Nordic cooperation. At that time, the EU and the development of EU law also seemed to many a more attractive field of study than the more limited Nordic cooperation. One might therefore say that since Swedish and Finnish accession to the EU in 1995 (Denmark has been a member since 1973), it was Europe, and not "Nordicness", that came into the focus of Nordic political and legal debates.

Today, the situation seems to have changed, at least partly. The economicpolitical crisis within the European Union has produced discussions on different ways of organizing societal life in the North and South of Europe, but also on the future of the so-called Nordic model with social welfare as a key element. Awareness of the Nordic countries as model societies has been strengthened and, at the same time, new openings for cooperation between the Nordic countries have been presented - even a modest relaunch of the proposal for a Nordic federal state. ${ }^{13}$ It may also be maintained that there seems to be more external interest in "Nordic law" and ways to continue Nordic cooperation than some years ago, when the Nordic countries were considered more peripheral. ${ }^{14}$ That said, however, it should be stressed that

\footnotetext{
${ }^{12}$ See e.g. Letto-Vanamo P (1998) and Bernitz U (2000).

${ }^{13}$ See Wetterberg G (2010) and Wenander H (2014).

${ }^{14}$ The explorer spirit of Nordic cooperation, active in the 1870s-1930s and again when Nordic legislative cooperation was revitalized after World War II, is no longer present on
} 
Nordic cooperation in the field of law is not as obvious a feature as it used to be. Revitalization is definitely needed. ${ }^{15}$

\section{The Impact of "Old" Unions}

The Nordic countries are in fact five countries with different histories, but also with different laws. Law is always national, even if national law itself need not be of national origin: it can be a result of borrowing law or legal institutions from other countries or other legal systems. Indeed, the law of the Nordic countries - even if Roman law was never the law of the land - is firmly based on principles within private law that have their origin in a common European past in the field of law.

Ever since the Middle Ages, the Nordic countries have thus been exposed to influences from Canon law and Roman law. The law of the Church, Canon law, and scholars educated at universities in Southern Europe and Germany were important in forming legal thinking in the Nordic countries in the Middle Ages. They also played a significant role in the process of writing down local law, which mostly occurred in the $12^{\text {th }}$ and $13^{\text {th }}$ centuries. Thus, there is a long tradition of written law.

The early wave of Roman law influence (that of the ius commune), typical of many western European countries since at least the $16^{\text {th }}$ century, did not have the same impact in the Nordic countries as elsewhere in Europe. Since end of the $15^{\text {th }}$ century it was possible to study law also at a Nordic university, but students were few, and for a full study of law its was necessary to go abroad. A university-trained legal profession (with an exam) and legal science in the North are phenomena of the $18^{\text {th }}$ or $19^{\text {th }}$ centuries. ${ }^{16}$ Since that time, the scholarly legal tradition has been that of continental Europe, with Nordic lawyers actively applying legal concepts and ideas from other countries. However, it was only rather late that so-called learned

the same scale. At the meeting of Nordic lawyers in 2005 the question whether Nordic legal cooperation had any further role to play actually came under discussion, with the conclusion that more fuel was necessary if this "Nordic dimension" was to maintain its position, Dahl B (2005). Four years later a proposal was launched for more effective Nordic cooperation in implementing European (EU/EEA) legislation. Buskjaer Christensen M, Fenger N (2009).

15 The newest initiative Backer IL (2018).

${ }^{16}$ Tamm D (2009), Björne L (2002). 
law and professional educated lawyers started to have an impact on lawmaking.

In the Middle Ages, important principles of local law were written down in all the Nordic countries, and even if many similarities can be found in the texts, significant differences also arose due to local peculiarities. In order to understand how law and legal contacts developed and functioned between the countries of the North, it is important to stress how the remains of earlier unions between the countries are still visible.

In fact, we may talk of a western Nordic group consisting of Denmark, Norway and Iceland, and of an eastern group consisting of Sweden and Finland. Denmark and Norway were united under the same King from 1380. Finland formed part of Sweden until 1809. The Danish-Norwegian monarchy (also including Iceland) and its law developed differently from the Kingdom of Sweden (of which Finland at that time formed part). In the late $17^{\text {th }}$ century, Danish and Norwegian laws were unified on the basis of two major law books or codes (in principle containing basic rules in all fields of law), the Danish Code of $1683^{17}$ and the Norwegian Code of 1687, the Norwegian Code being based on the Danish Code, leaving aside much of old Norwegian law. ${ }^{18}$ Thus, Danish and Norwegian law were for centuries to a high degree virtually identical.

To a certain extent this idea of common Danish-Norwegian legal science also survived after 1814, the year Norway entered into a union with Sweden (until 1905) - but without adopting Swedish law. Sweden and Finland have always had a common legal basis, with its most material form in the shape of the Swedish Code of $1734^{19}$. Swedish law also remained the law of Finland and the Swedish language the official language ${ }^{20}$ even after 1809 , when Finland became an autonomous Grand Duchy (until 1917) within the Russian Empire. Still, the relation to Russia has had an impact on Finnish society as well as on societal and legal thinking, which may differ from that of the other Nordic countries. Especially, attitudes towards law, have been

\footnotetext{
${ }^{17}$ See Tamm D (1984).

${ }^{18}$ Tamm D (2011).

${ }^{19}$ See Wagner W (1986).

${ }^{20}$ Today, Finland has two official languages, Finnish and Swedish; For instance, legislation is always published in both languages. Thus, in the following chapters references to the legislation in Finland can be found both in Finnish and Swedish.
} 
more legalistic ${ }^{21}$ in Finland than in the other Nordic countries. In addition, so-called Scandinavian Legal Realism played a less important role than in Sweden and Denmark. Furthermore, Finland became involved in Nordic cooperation later than the other Nordic countries, in fact only after becoming a sovereign state.

Nonetheless, strong links exist between Sweden and Finland, for example as to preparation of new legislation. In Swedish legal tradition, including judicial argumentation, preparatory works for new legislation (travaux préparatoires) ${ }^{22}$ play an important role, as indeed they do in Denmark and Norway. ${ }^{23}$ Reference to Swedish material has often been used when drafting new Finnish legislation. Indeed, the fact that legislation in Sweden and other Nordic countries is taken into consideration and referred to forms part of the preparatory procedure for new laws in Finland.

If such a development, which aimed at harmonizing the law, had not been counterbalanced by active legal collaboration since the $19^{\text {th }}$ century, the Nordic countries might have continued as two or more clearly distinct legal groups within the civil law family. This cooperation, discussed later in more detail, was based not only on common histories and on the idea that the Nordic countries share a common idea of the law, but also on the conviction that the need for necessary legal reforms due to rapid developments, especially in international trade and commerce, could best be met by common efforts. Hence, Nordic legal collaboration not only has a long history. It has also achieved many concrete results, with common legal norms as examples, contributing to the feeling that such thing as a common Nordic "core" of the law does exist. ${ }^{24}$

Moreover, this active cooperation is a characteristic feature of what in a broader sense could be called "Nordic legal culture". A sense of coming from and having studied the law of a Nordic country is part of a Nordic lawyer's identity. The Nordic lawyers' meetings, which as we have seen started in 1872, have since continued at different stages. Matters of common legal interest remain on the agenda. At the same time, these meetings, which

\footnotetext{
${ }^{21}$ In the so-called Russification period during the decades before and after 1900, still during the autonomous period, legalism was a concept that referred to retaining Swedish legislation that was (still) in force in Finland as a symbol of "the rule of law."

${ }^{22}$ See further Husa $\mathrm{J}$ in this book.

${ }^{23}$ Wilhelmsson $\mathrm{T}$ (1985).

${ }^{24}$ Carsten G (1993).
} 
are in principle only conducted in Nordic languages, have still contributed to the feeling among Nordic lawyers of having something more in common amongst themselves than with lawyers from other countries. At these meetings, participants are supposed to speak the language of their own country, ${ }^{25}$ and to adapt their way of speaking to an audience which - not always without difficulty - is supposed to understand you. This means that the meetings also form part of a common Nordic legal identity across language borders. ${ }^{26}$

\section{Common Ways of Legal Thinking}

If we compare Nordic societies, many relatively well-known similarities clearly exist - indeed, some of these still play a role in the development of legal institutions and legal thinking. The countries are all rather small, and their societies quite homogenous and egalitarian. ${ }^{27}$ For a long time, great majority of population was living on the countryside. Social and legal cultures have therefore been characterized as determined by a peasant or rural culture, as distinct from urban culture. At the time, you cannot neglect impacts of the strong Monarchy introduced in the waves of the Lutheran Reformation, which took place in the $16^{\text {th }}$ century.

Both are rightly and often mentioned as important factors in understanding Nordic society and its legal institutions. ${ }^{28}$ Here, so the argument goes, at least some reasons exist for the dominance of the Nordic idea of a "good" state and for implementing the idea of the social state, characterised not only by ways of organising conflict resolution ${ }^{29}$ or institutions public law ${ }^{30}$ but also by fundamental ideas of private law. A social dimension has been typical of Nordic legal thinking, for example with a focus on protecting the weaker party in contract law, especially in labour or consumer contract

\footnotetext{
${ }^{25}$ For participants from Finland, however, this means only the Swedish language. The Finnish language belongs among Indo-European languages and cannot be understood on the basis of knowledge of the other Nordic languages.

${ }^{26}$ Early results of this Nordic identity included the Nordic legal encyclopaedia (Nordisk Retsencyklopedi 1878-1899) and the Nordic journal Tidskrift for Retsvidenskab (today Tidsskrift for Rettsvitenskap, 1888-).

${ }^{27}$ See further Petersen $\mathrm{JH}$ and Niemi $\mathrm{J}$ in this book.

${ }^{28}$ Tamm D (2010).

${ }^{29}$ See further JØ Sunde and Nylund A in this book.

${ }^{30}$ See further Mäenpää $\mathrm{O}$ and Fenger $\mathrm{N}$ in this book.
} 
relationship ${ }^{31}$. One can also speak of one-norm societies with their interplay between state and church that could provide fruitful soil for modern, universal practices in Nordic welfare states. ${ }^{32}$

The Nordic countries were modernized relatively recently, generally speaking only during the $19^{\text {th }}$ century, with the first wave of industrialization. In this process the state played an important role. At the same time, the Nordic countries are often characterized as countries in which the borders between civil society and the State are blurred. Indeed, the concepts of state and society do seem to be interchangeable in many ways. Hence, many societal and legal institutions have in a way been corporatist by nature in order to ensure representation of various social interests - for instance, boards with conflict-solving functions or committees for drafting new legislation. ${ }^{33}$ At the same time, popular control and a common sense of justice have to varying degrees been brought into court proceedings through participation by laymen. Mention can also be made of state supervision of the legality of public administration by the (parliamentary) ombudsman - an institution with its origin in Sweden.

In all Nordic countries the public sector and public administration occupy a huge dimension and play an important role. The system of conflict resolution between public authorities and citizens varies to a high degree. Litigation between the administration and the citizen in Sweden and Finland is dealt with by specific administrative courts organized in a hierarchy which differs from that of ordinary courts. Other Nordic countries have no such organised administrative court system. For example, administrative cases in Denmark are dealt with by a plurality of different organs or boards. Most of these are set up for specific administrative complaints such as taxes, social legislation, ${ }^{34}$ competition, environmental protection, energy providers, and consumer affairs, while the ordinary courts (with notable exceptions) normally have the last word in these matters.

\footnotetext{
${ }^{31}$ Wilhelmsson T (1987); See also further Bärlund J and Moegelvang-Hansen P in this book.

${ }^{32}$ Stenius H (2013).

${ }^{33}$ Letto-Vanamo P (2014).

${ }^{34}$ Tax law and social security complaints in Denmark and Norway are also decided by organs similar to ordinary courts. In these fields more similarities exist between the Nordic countries than in other parts of the complaints system.
} 


\section{Pragmatism and Realism}

\subsection{Against a Civil Code}

Often Nordic legal peculiarities are described by using expressions: pragmatism, realism, absence of formality, an uncomplicated and understandable legal style, transparency, equality, and avoidance of extremes. These peculiarities of legal thinking can be forceful when maintained not by the Nordic countries individually but in common. The Nordic countries still feel that in these respects they are closer to each other than to other countries. This also explains a certain reluctance towards what is seen as trends in over-administration and centralization within the European Union. These values were also cornerstones of the original Nordic project of legal cooperation.

"Nordic-ness" is in some ways a consequence of the late professionalization of legal culture in these countries. For a long time one could speak of nonprofessional or lay-dominated legal cultures. This again has defined court systems and legal procedures ${ }^{35}$, but could also explain at least partly why Nordic legal culture is even today characterized by the term "pragmatism". ${ }^{36}$

In all the Nordic countries the most important source of law - and the key instrument for legal-societal changes - has been parliamentary legislation. Thus, the most important legal actor is the legislator. The countries don't have constitutional courts, and only seldomly the authority of the legislator is questioned by the judiciary. ${ }^{37}$

Ongoing European discussion of law addresses the question whether it is appropriate to collect rules in wide fields of law in written law books, socalled codifications or codes in the shape of systematic collections of law covering general principles and more detailed rules in several areas, and which are supposed to be the main source of law. In particular, the question has been raised whether codifications covering civil law, i.e. the law of obligations (in contract and tort), property law, family law, and law of succession, should be seen as a positive feature, or as one that complicates finding the law and causes stagnation in law-making.

\footnotetext{
${ }^{35}$ See further JØ Sunde and Nylund A in this book.

${ }^{36}$ Zweigert K, Kötz H (1998).

${ }^{37}$ Wind M, Follesdal A (2009), see also further Husa J in this book.
} 
Modern civil law codifications, including more or less detailed rules on general doctrines (principles) of civil law such as the French code civil (1804) or the German Bürgerliches Gesetzbuch BGB (1900), have been models for many countries covering all traditional fields of private law. After the fall of communism in 1991, work on codification was intensified in former Eastern-bloc countries. Indeed, the great majority of European countries today have a new or totally revised code on private law, considered as a national civil code which forms the basis of the law. Some countries even have a specific commercial code, which is also unknown in the Nordic countries even if some individual acts may have specific rules on commercial relations between professionals.

The Nordic countries, however, have been resistant to these large-scale law projects. They have chosen to enact the necessary legislation separately in discrete statutes, many of which were drafted on the basis of Nordic initiatives and discussions. Exceptions are found within penal ${ }^{38}$ and procedural law. In Denmark, a code of procedure with more than a thousand articles came into force in 1919. The realistic, pragmatic approach, together with general democratization tendencies, led to reforms of legal procedure and the Swedish court system in $1948,{ }^{39}$ while similar reforms in Finland were realized only as late as the 1990s.

Within civil law, issues such as contracts, marriage or succession have been regulated by more or less independent acts, many of which are the result of common Nordic drafting and exchange of ideas. Indeed, the non-existence of broad, complex civil codes has enabled Nordic legislative cooperation. In Denmark, some important areas of law such as the general principles of tort law (on liability for non-contractual damages) are more or less exclusively based on the practice of the courts. At the same time, general doctrines (principles) of law have been developed, mainly by legal scholarship, while active cooperation with Nordic colleagues even today forms an important part of the daily work of many legal scholars.

There are also Nordic associations and/or yearly meetings for scholars and other lawyers within different disciplines, e.g. administrative law, criminal law, contract law and family law.

\footnotetext{
${ }^{38}$ See further Lappi-Seppälä T and Nuotio K in this book.

${ }^{39}$ See further Modéer KÅ (1999).
} 
The idea that Nordic law should be codified in a complete Nordic code gained currency in 1896, when this work was carried through in Germany in the shape of the BGB, which came into force in 1900. German legal thinking and the drafting of the BGB were well known in the Nordic countries, and revived the old discussion of codifying civil law. In 1899 one of the more outstanding Nordic lawyers of the time, the Danish professor Julius Lassen, took the opportunity to launch the idea of creating a modern Danish civil code. ${ }^{40} \mathrm{He}$ was much driven by his interest in German systematic legal thinking but was also critical of the way the German Code was drafted. In this connection he mentioned that a common Nordic civil code should be the final goal. In Norway especially, this idea was seen as driven by some sort of megalomania, but in Sweden it was taken as a chance to revive Nordic legal cooperation, which after a very active start had somehow come to a halt. Inspired by Lassen, a member of the Swedish parliament took the initiative and proposed that Nordic legal cooperation should be extended to new fields. The goal was not a new code.

This did not lead, nor was it intended to lead, to the drafting of a Nordic code. The scope was narrower when so-called civil law committees were set up in Denmark and Sweden (1901) and later in Norway as well. The first Nordic legislative programme was accepted, and legal problems concerning contract, sales and securities were seen as suitable subjects for cooperation. In the 1909 programme even family law issues were mentioned, with planned cooperation in the fields of marriage and economic relations between spouses. ${ }^{41}$ There have since been two standing committees, a civil law committee and a family law committee, in each country. ${ }^{42}$

The idea of creating a new Nordic civil law book was never seriously seen as a realistic option. Indeed, drafts were drawn up but the endeavour was

\footnotetext{
${ }^{40}$ Tamm D (2011), p 135-139.

${ }^{41}$ In family law especial objects of cooperation were marriage and divorce, property relations between spouses, guardianship and the relationship between parents and children. See further Lund-Andersen I and Kronborg A in this book.

${ }^{42}$ In the field of civil law the most important results of Nordic cooperation were nearly identical statutes on sale, agency, and on the conclusion and nullity (non-validity) of contracts. See further Bärlund J and Moegelvang-Hansen P in this book.
} 
never accomplished and these drafts never led to a Nordic civil code. ${ }^{43}$ Creating a code, and even more a Nordic code, is a big issue, and much harmonization would be needed before such a project could seriously be considered. Nordic lawyers did not see such a project useful, and prioritised flexibility in law-making above creation of a coherent codified private law system including both general principles and detailed rules of several fields of private law.

Later proposals for a common European civil code also met attitudes among Nordic legal professionals that were more sceptical than enthusiastic. Even today, Nordic lawyers prefer discrete acts, which are easier to formulate and more flexible to amend, and which do not govern the law and legal thinking too much but allow pragmatism and judicial and scholarly interpretations to meet practical ends.

\subsection{Realism}

Nordic law and especially Nordic legal scholarship are heavily indebted to tremendous efforts, especially in Germany in the $19^{\text {th }}$ century, to create a method of developing the law based on profound thinking on coherence in law and legal concepts. However, this thinking never became dominant and was gradually superseded by the idea of the law as serving social purposes, and thus having to be not only theoretically on a high level but also available as a tool for practical purposes. Great German lawyers such as F.C. von Savigny, Rudolf von Jhering and Bernhard Windscheid were familiar to leading Nordic lawyers, who might even have been among their students at some time.

Thus, it is important to stress that those lawyers who were instrumental within Nordic legal cooperation would have had a common background of legal knowledge based on German authorities, even if they represented different Nordic legal systems. ${ }^{44}$ This was clearly the case in Finland and Denmark, whereas $19^{\text {th }}$ century Norwegian lawyers were more critical

\footnotetext{
${ }^{43}$ Still, in 1948 the Danish law professor, Frederik Vinding Kruse, also acting on his own initiative, presented to the Nordic lawyers' meeting a draft of a Nordic civil code, and in 1962 a second draft.

${ }^{44}$ Links do exist between Nordic law and the so-called "civil law family" represented e.g. by German law. But Nordic cooperation was still an important feature in creating and maintaining a way of legal thinking - and legal style - different from the highly abstract German approach.
} 
towards the German approach. Still, when national legal scholarship ${ }^{45}$ emerged in the Nordic countries during the late $18^{\text {th }}$ and $19^{\text {th }}$ centuries, this happened to a high degree based on German inspiration by adapting German legal ideas and relying heavily on textbooks by German legal authors. In this way, Nordic law became influenced by a Roman Law-based terminology and systematization, still visible today in the Nordic legal systems. At the same time, ideas of German legal scholarship and state theory played an important role in the development of public law in the Nordic countries.

However, it must be stressed that German legal thinking was not accepted uncritically. In particular, the work of the courts did not involve too much theoretical reasoning. We often talk of Nordic pragmatism in law. In other words, practical solutions have been preferred to those based on what in the Nordic countries is often seen as too much theoretical thinking or exaggerated abstraction. This tradition traces its roots back to the $19^{\text {th }}$ century.

In Denmark one highly influential lawyer was Anders Sandøe Ørsted (17781860). In an impressive output of books and legal studies, to a high degree inspired by his reedling of contemporary German legal scholarship, Ørsted laid a basis in Danish and Norwegian law for a practical way of looking at the law. ${ }^{46}$ From the 1920s, Nordic legal philosophy was influenced by the school of so-called Scandinavian Realism. This was mostly a Swedish and Danish phenomenon. In Sweden the main influence was the so-called Uppsala School, which made Scandinavian Realism as a philosophical school well known abroad, through such names as Axel Hägerström and Vilhelm Lundstedt. The Uppsala School had a significant impact on the thinking and argumentation of many Nordic lawyers, too. The Swedish lawyer Karl Olivecrona and the Danish lawyer Alf Ross are often seen as the most representative and internationally known legal scholar of the realistic movement. However, in Norway natural law thinking also came to play a role, while in Finland a more conceptual way of legal thinking truer to its German inspirations predominated.

Realism meant that legal theory was reluctant to recognize the importance of general legal concepts for argumentation and stressed that reflection on

\footnotetext{
${ }^{45}$ E.g. Montgomery R (1889), Lassen J (1892).

${ }^{46}$ Tamm D (1978).
} 
how the courts would actually reach their decisions was the proper object of the law. In this connection the concept of "forholdets natur" (the nature of the matter) or "reella överväganden" (real considerations) formed part of the basis of the Danish and Swedish doctrine of legal sources. At the same time, the idea of law as an instrument of "social engineering" formed a crucial element of Scandinavian realism. ${ }^{47}$

The dominance of German (conceptual) jurisprudence diminished in Finland, above all through influences from Analytical Philosophy and the so-called Analytical School of Law since the 1950s. ${ }^{48}$ Analytical criticism focused mainly on "conclusions from concepts". But concepts were not neglected. They played a heuristic role - concepts were necessary for clarifying and classifying legal problems. ${ }^{49}$ Today, legal principles have become important, but concepts are still in focus: they prepare the way for principles-based legal argumentation. Nevertheless, Finnish legal scholarship can be characterised as more theoretical than in the other Nordic countries.

At the same time, Finnish legal scholars share a view of three - almost equally powerful - legal actors (the legislator, the judiciary and legal scholarship), and the ethos of the active role of legal science as a means of changing the law and society. Legal scholarship, at least in the meaning of legal dogmatics, is understood as one - but just one - of the legal practices that continuously produce and reproduce the legal order. According to modern Finnish legal theorist Kaarlo Tuori, legal scholarship contributes to the development of the legal order through its very results, such as systematization of law. After a scholar's proposals have found general acceptance, for instance systematic divisions or new concepts, form an integral part of "legal-cultural pre-understanding" and also unfurl their

${ }^{47}$ Pihlajamäki H (2004), Björne L (2007).

${ }^{48}$ Influences in legal thinking were closely connected to Finnish philosophy of the 1960s and 1970s (e.g. G.H. von Wright and Jaakko Hintikka), which was strongly influenced by Anglo-American analytical philosophy.

${ }^{49}$ The most important changes in Finnish society can be dated to as late as the 1970s. Since then it has become possible to speak of a welfare (social) state. The decade was characterised by various democratization and modernisation procedures: for instance, reforms to the school system, university education, and part of the court system.

Approximation of legal science to other social sciences was required in terms of legal education at universities. Moreover, trends in legal research changed, visible e.g. in dissertations and other academic works pointing out the "social dimension" of law. 
heuristic effects in other legal practices such as law-making and adjudication. ${ }^{50}$

\section{Towards Common Legislation}

In general, the (early) procedure for creating common Nordic legislation could be described as follows. Work towards a common Nordic statute could start when one of the countries took on the task of preparing a written proposal that could be discussed by the national committees. After that the committees would meet regularly and conclude their work with a draft statute. With that in mind, each country prepared its own draft with necessary explanations. After that the draft could be submitted to the national parliament, and eventually be issued as a statute. The statutes were and are considered national law. Moreover, a national statute can easily differ from statutes on the same subject issued in the other Nordic countries. Nordic harmonization does not mean that statutes or legislation are necessarily identical, but on the other hand differences would normally not be too obvious. It should also be remarked that even if statutes are identical, national courts are free to arrive at their own interpretations of the law concerned. ${ }^{51}$

Thus, the main players in achieving legal goals were the national committees or working groups. In each country, a committee was nominated to prepare a national draft. In the case of bills of exchange, a German statute on this theme was chosen as the model. The national committees worked and held meetings both separately and together before presenting their respective parliament with a draft statute. In the case of bills of exchange, the committees had worked so closely together that identical drafts could be presented and accepted as statutes in the 1880s. The next steps for legislative cooperation were common laws on commercial registration and statutes on registered trademarks. In the decades from 1872 to the 1890 s, notable results were achieved in this way in terms of creating a common Nordic commercial law.

Nordic cooperation originated in a spirit of collaboration as something positive and useful in the field of law. Based on private initiatives and

${ }^{50}$ Tuori K (2011), p 151-153.
${ }^{51}$ Tamm D (1985). 
common, voluntary efforts, many concrete results were achieved. Active cooperation continued after World War II. In 1948, however, cooperation took on a more official dimension when the Swedish, Danish and Norwegian Ministers of Justice decided on a common legislative programme including ten topics, and invited Finland and Iceland to take part in cooperation. At the same time, a permanent organ, the Nordic Committee for Legislative Cooperation (Nordisk udvalg for lovsamarbedje), was founded. ${ }^{52}$ Later legislative cooperation was based on these programmes.

In 1962, Nordic cooperation acquired a written foundation in a treaty concluded in Helsinki. From a legal perspective, the Helsinki Treaty could be seen as a codification of former cooperation. But it has also been seen as a result of Denmark's and Norway's interest in cooperating with the European Economic Community (EEC). Thus, the Treaty would make Nordic cooperation visible in the eyes of "more formalistic Germans and Frenchmen" in negotiations on European cooperation. ${ }^{53}$ According to the Helsinki Treaty, the Nordic countries would work for legal unity, for "uniformity of regulation throughout the Nordic countries in as many respects as possible". The aim is to attain the greatest possible uniformity in private law as was traditionally the scope of cooperation. However, the Treaty also mentions as a goal the promotion of unity as regards penal (criminal) law and penal sanctions.

In fact, close cooperation has long existed between Nordic researchers in penal (criminal) law $^{54}$, while the capacity of criminologists has played an important role when execution of punishments has been under discussion. A Nordic journal of criminal law (Nordisk Tidsskrift for Kriminalvidenskab) was founded more than a hundred years ago. However, national politics often follow other lines: criminal policy has been an important political issue in most Nordic countries. This often leads to gaps between popular understanding and political goals, and recommendations by penal lawyers and criminologists. ${ }^{55}$

According to the preamble to the Treaty, the governments of the Nordic countries agreed that the provisions stemmed from a desire "to promote and

\footnotetext{
${ }^{52}$ Boucht J (1999).

${ }^{53}$ Wiklund C (1987), Petrén G (1983).

${ }^{54}$ See further Lappi-Seppälä $\mathrm{T}$ and Nuotio $\mathrm{K}$ in this book.

55 Träskman P (2012).
} 
strengthen the close ties existing between the Nordic peoples in matters of culture, and of legal and social philosophy, and to extend the scale of cooperation between the Nordic countries." In any case it was, and still is, important to point out that legal cooperation should be promoted within a community of common values. Secularism, democracy, respect for the individual, social considerations, and protection of the weaker party are often mentioned as Nordic values. These are also influential in legal matters.

At the same time, cooperation should be based on the principle of "Nordic utility" (in Swedish nordisk nytta), which means that cooperation should only take place where the common good of the Nordic countries can be achieved. The activity concerned should not only develop a Nordic feeling of unity but should also strengthen Nordic competence and competitive abilities. Thus, it is important to consider whether the goal in a specific case tends towards achieving Nordic unity or simply exchanging information or more superficial harmonization.

In the 1970s, Nordic cooperation was formalized further with the founding of the Nordic Council of Ministers. Today, government cooperation in the area of legislation is led by the Nordic ministers of justice, who make up their own "Law Council". The key actor in practical work and in preparations for meetings of the Council of Ministers is the Committee of Senior Officials for Legislative Affairs, which consists of representatives of all the Nordic countries and autonomous territories. More generally, Nordic cooperation has been seen as part of intergovernmental cooperation based on Nordic conventions - covering issues of Nordic mobility of citizens, such as taxation, family relations, or social security. ${ }^{56}$

However, no conventions have been agreed in justice affairs, so that legal cooperation has continued on a traditional - informal and voluntary - basis. Still missing, though, are Nordic organs with supranational functions, such as the EU Court, or a Nordic acquis, or a binding set of common Nordic legal norms. Moreover, legislative cooperation is seen as a tool for the Nordic countries in their work in promoting the fundamental common principles of Nordic legislation.

${ }^{56}$ Wenander H (2014). 


\section{Perspectives for the Future}

After Sweden and Finland joined the EU in 1995, Nordic cooperation was seen as endangered, as already noted above. However, according to changes to the Helsinki Treaty (1995) Nordic cooperation is also seen as part of broader cooperation within the European Union. Nonetheless, the wish remains "further to renew and expand cooperation between the Nordic countries in the light of the greater participation by the Nordic countries in the process of European cooperation." Nordic cooperation lost some of its momentum after the 1990s, and it remains to be seen whether the recommendations of the Helsinki Treaty can be maintained. In many fields of law, Nordic cooperation seems to be merely a supplement to European Union regulation. ${ }^{57} \mathrm{But}$, at the same time, unity between the Nordic legal orders was never so widespread earlier as it is today.

An important Nordic-related question today, therefore, is the future of Nordic legal cooperation, especially within the framework of the European Union. ${ }^{58}$ Norway and Iceland are not members of the European Union but they are closely associated with the Union through their membership in the European Economic Area (EEA). Many tend, however, to underrate the impact of the European Union in this respect by pointing to Nordic cooperation as based on common tradition(s) and values rather than on specific economic goals (like that of the common market). Others are more concerned that Nordic cooperation - based on goodwill, informality and $\mathrm{ad}$ hoc meetings among civil servants in Brussels - has lost its drive and its proactive nature, and that it needs to be revived; otherwise it will decline completely. ${ }^{59}$ What remains is the fact that Nordic lawyers to a great extent belong to a Nordic legal community, even if many of them have lost their conviction of the importance of Nordic cooperation.

However, much has changed during recent decades. European legal harmonization has touched many fields of law. Consumer protection, once one of the main topics of Nordic cooperation, has been fully harmonized by EU legislation. Even criminal law has been partly Europeanised, with considerable impact on the one-time "Nordic rational and human criminal policy". Danish professor Ole Lando and the commission he chaired were

\footnotetext{
${ }^{57}$ Wilhelmsson T (2005).

${ }^{58}$ Dahl B (2005).

${ }^{59}$ Backer IL (2018).
} 
successful in initiating the European Principles of Contract Law (PECL), thus furthering ideas towards a European civil code. Nordic legal scholars have participated in several European harmonisation projects (i.e. Draft Common Frame of Reference: Principles, Definitions and Model Rules of European Private Law, DCFR), EU jurisprudence has produced new legal principles, such as protection of legitimate expectations and proportionality, which have had an impact on Nordic legal thinking. More often, too, the English language is used even in communication between Nordic legal professionals.

In recent decades, Nordic legislative cooperation has also lost much of its former dynamism. At least, its nature has changed due to the fact that many important areas of law have been taken over by legislation within the European Union. Today, Nordic legislative cooperation can be characterized as "reactive" as opposed to "proactive". Thus, the agenda for discussions on Nordic uniformity of laws is mostly defined by the EU legislator and focused on proposals drafted in Brussels, or on national implementation of EU regulation. Moreover, legislative details are discussed instead of common legal principles. ${ }^{60}$

At the same time, Nordic attitudes to the European Union have been characterized as sceptical. In all the Nordic countries the democratic deficit, and problems of transparency in the EU, have been on the agenda. Today, the economic and political crisis has even increased criticism against the EU in Finland, which has been the only Nordic country to accept the Euro. Still, the real challenges to Nordic cooperation today do not seem to come from the European Union but from a weakening of the Nordic spirit. The tradition and also the framework including Nordic meetings, associations, journals, as well as legislative drafting procedures and the provisions of the Helsinki Treaty concerning Nordic legal cooperation still exist even in much wider fields than a hundred years ago. The main challenge today is how to maintain the Nordic spirit and to revitalize interest in protecting, or even furthering, common Nordic values.

\section{References}

Backer IL (2018) Styrket nordisk lovsamarbeid: Muligheter og utfordringer. Copenhagen, Nordisk ministerråd

${ }^{60}$ Buskjaer Cristensen M, Fenger N (2009). 
Bernitz U (2000) Nordic Legislative Cooperation in the New Europe - A challenge for the Nordic Countries in the EU Perspective. Stockholm Institute for Scandinavian Law 39:39-45

Björne L (2002) Den konstruktiva riktningen - Den nordiska rättsvetenskapens historia, Del III, 1871-1910. Lund, Institutet for rättshistorisk forskning

Björne L (2007) Realism och skandinavisk realism - Den nordiska rättsvetenskapens historia, Del IV, 1911-1950. Lund, Institutet for rättshistorisk forskning

Boucht J (1999) De nordiska juristmötena och rättsgemenskapen i Norden. Defensor Legis 5:748-775

Buskjær Christensen M, Fenger N (2009) Nordisk samarbejde om gennemførelse af EUog EØS-lovgivning. Realiteter og perspektiver. TemaNord 2009:575. Copenhagen, Nordisk ministerråd.

Carsten G (1973) Hundert Jahre Nordischer Juristentag: 1872-1972. Rabels Zeitschrift für ausländisches und internationales Privatrecht / The Rabel Journal of Comparative and International Private Law, p 80-100

Carsten G (1993) Europäische Integration und nordische Zusammenarbeit auf dem Gebiet des Zivilrechts. Zeitschrift für europäisches Zivilrecht p 335-348

Dahl B (2005) Har det nordiske lovsamarbejde udspillet sin rolle? In Árnason RT (ed) Forhandlingerne ved, Det 37. nordiske jurismøde i Reykjavík 18.-20. august 2005, Band 1, pp 155-173

Glenn HP (2005) On Common Laws. Oxford, Oxford University Press

Husa J (2000) Guarding the Constitutionality of Laws in the Nordic Countries: a Comparative Perspective. American Journal of Comparative Law, p 345-382

Husa J (2004) Classification of Legal Families Today. Revue de Droit Comparé 56:11-23 Husa J (2015) A new introduction to comparative law. Oxford, Hart Publishing

Husa J, Nuotio K, Pihlajamäki H (eds) (2007) Nordic Law - Between Tradition and Dynamism, Ius Commune: European and Comparative Law Series, vol. 66. Cambridge, Intersentia

Lassen J (1892) Haanbog i Obligationsretten - Almindelig Del. Copenhagen, Gad

Letto-Vanamo P (ed) (1998) Nordisk Identitet, Helsinki, Institutet för internationell ekonomisk rätt

Letto-Vanamo P (2013) Nordische Rechtsgeschichte - eine europäische Variante? Zeitschrift für Neuere Rechtsgeschichte 35:112-124

Letto-Vanamo P (2014a) Nordic Democracy Facing the EU: Traditions, Myths and Challenges. In Fichera M, Hänninen S, Tuori K (Eds), Polity and Crisis. Reflections on the European Odyssey. Farnham, Surrey, Ashgate, p 217-234

Letto-Vanamo P (2014b) Judicial Dispute Resolution and its Many Alternatives: The Nordic Experience. In Zekoll J, Bälz M, Amelung I (eds), Formalisation and Flexibilisation in Dispute Resolution. Leiden, Brill, p 151-164

Lidbom C (1973) Den nordiska rättsenhetens problem idag. Svenska Juristtidning, p 273278

Matteucci M (1956) The Scandinavian legislative co-operation as a model for a European co-operation. In The Swedish Branch of the International Law Association, The Swedish Association for International Maritime Law (eds) Liber Amicorum to Algot Bagge. Stockholm, Norstedt, p 136-145 
Modeer KÅ (1998) Nordisk juristkultur en del av rättskulturen - Förändring och stabilitet. In Letto-Vanamo P (ed) Nordisk identitet. Nordisk rätt i europeisk gemenskap. Helsinki, Institutet för internationell ekonomisk rätt, $\mathrm{p} \mathrm{1-14}$

Modéer KA (2005). Renässans för den nordiske juristen? Tidskrift utgiven av Juridiska Föreningen i Finland, p 58-70

Montgomery R (1889) Handbok i Finlands allmänna privaträtt I. Helsinki, G. W. Edlund

Olsen JP, Svedrup BO (eds) (1998). Europa i Norden: Europeisering av nordisk samarbeid. Oslo, Tano

Petrén G (1983) Helsingforsöverenskommelsens tillkomst. Nordisk Tidskrift för vetenskap, konst och industri, p 62-72

Pihlajamäki H (2004) Against Metaphysics in Law: The Historical Background of American and Scandinavian Legal Realism Compared. American Journal of Comparative Law, p 469-488

Smits J (2007) Nordic Law in European Context. Some Comparative Observations. In Husa J, Nuotio K, Pihlajamäki H, Nordic Law - Between Tradition and Dynamism, Ius Commune: European and Comparative Law Series, vol. 66. Cambridge, Intersentia, pp 55-64

Stenius H (2013) A Nordic Conceptual Universe. In Haggren H, Rainio-Niemi J, Vauhkonen J (eds), Multi-layered Historicity of the Present - Approaches to Social Science History. Helsinki, University of Helsinki, Department of Political and Economic Studies, p 93-104

Tamm D (1978) Anders Sandøe Ørsted and the Influence from Civil Law upon Danish Private Law at the Beginning of the 19th Century. Scandinavian Studies in Law vol 22, pp 243-265

Tamm D (1984) The Danish code of 1683: An early European Code in an International Context. Scandinavian Studies in Law vol 28, pp 163-180

Tamm D, Andersen P, Vogt H (eds) (2011) How Nordic are the Nordic Medieval Laws: Proceedings from the first Carlsberg Conference on Medieval Legal History. Copenhagen, Djøf

Tamm D, Slottved E (2009). The University of Copenhagen: A Danish centre of learning since 1479. Copenhagen: University of Copenhagen

Tamm D (2011) The History of Danish Law: Selected Articles and Bibliography. Copenhagen, Djøf

Tamm H (1972) De nordiske juristmøder 1872-1972 - Nordisk retssamvirke gennem 100 år. Copenhagen, Nyt nordisk Forlag Arnold Busck

Tuori K (2010) Ratio and Voluntas: the tension between reason and will in law. Burlington, Ashgate

Träskman P (2012) Finsk, svensk och nordisk straffrätt - och den europeiska - några reflektioner. In Hyttinen T (ed) Rikoksesta ja rangaistuksesta. Juhlajulkaisu Pekka Viljanen 1952 26/8 2012. Turku, Turun yliopisto, p 257-70

Wagner W (1986) Das schwedische Reichsgesetzbuch (Sveriges Rikes Lag) von 1734. Klostermann, Frankfurt am Main

Wenander H (2014) Fri rörlighet i Norden. Nordiska gränshinder i rättslig belysning. Lund, Juristförlaget 
Wetterberg G (2010) The United Nordic Federation, Tema Nord 583. Copenhagen, Nordiska ministerrådet. Available www.norden.org/fi/julkaisut/julkaisut/2010-583. Accessed 21 June 2108

Wiklund C (1987) Helsingforsöverenskommelsens tillkomst. Nordisk Tidskrift för vetenskap, konst och industri, p 328-343

Wiklund C (2000) 1962 års Helsingforsavtal - den första heltäckande nordiska samarbetstraktaten. In Sundelius B, Wiklund C (eds) Norden i sicksack - Tre spårbyten inom nordisk samarbete. Stockholm, Santérus Förlag, p 91-103

Wilhelmsson T (1985) Den nordiska rättsgemenskapen och rättskälleläran. Tidsskirft for rettsvitenskap, p 181-197

Wilhelmsson T (1994) Social Contract Law and European Integration. Aldershot, Dartmouth.

Wilhelmsson T (2005) Det bristfälliga nordiska lagstiftningssamarbetet och Helsingforsfördraget. In Nordiska ministerrådet, Lagstiftningspolitik - Nordiskt seminarium om lagstiftningspolitik, TemaNord 516. Copenhagen, Nordiska ministerrådet, p 117-127

Wind M, Føllesdal A (eds) (2009) Nordic Reluctance towards Judicial Review under Siege. Special issue of Nordic Journal of Human Rights 27/2

Zweigert K, Kötz H (1998) An Introduction to Comparative Law. Oxford, New York, Oxford University Press

Pia Letto-Vanamo, LLD, professor, University of Helsinki

Ditlev Tamm, LLD, professor, University of Copenhagen 